\title{
Nóbelsverðlaunin í læknavísindum í ár endur- spegla mikilvægi sorphirðu og endurvinnslu
}

Japanski líffræðingurinn Yoshinori Ohsumi hlýtur Nóbelsverðlaunin í læknavísindum 2016 fyrir rannsóknir á sjálfsáti (autophagy), ferli sem gegnir lykilhlutverki við sorphirðu og endurvinnslu í frumum. Endurnýjun er mikilvæg fyrir vefjastarfsemi líkamans en ekki síður innan frumnanna sem mynda vefi. Frumur framleiða sífellt ný prótein og frumulíffæri eins og hvatberar fjölga sér eftir pörfum hverju sinni. Samhliða slíkri nýmyndun er mikilvægt að eldri og oft skemmdar afurðir frumunnar séu brotnar niður og niðurbrotsefnin síðan nýtt til frekari uppbyggingar. Frumur bregðast einnig við áreiti eins og svelti með pví að auka sjálfsát sitt. Pannig fást aukin byggingarefni til pess að viðhalda starfsemi frumunnar í erfiðum aðstæðum.

Lengi vel var ekki vitað hvernig slíkt niðurbrot fer fram, en um miðja 20. öldina greindi Christian de Duve leysikorn (lysosome) í frumum með smásjárgreiningum. Leysikornið er niðurbrotsstöð frumunnar, par sem stórar próteineiningar og frumulíffæri eru brotin niður. Christian greindi líka leið pessara frumuhluta í leysikornið og nefndi ferlið sjálfsát. Pannig mátti sjá af smásjármyndum að tvöföld himna myndast í umfrymi og umlykur efni til niðurbrots. Himnubólan lokast og rennur síðan saman við leysikornið, par sem súrt umhverfi og ensím eru til staðar sem eru nauðsynleg fyrir niðurbrot. Christian de Duve fékk Nóbelsverðlaun fyrir pessar rannsóknir 1974. Hins vegar var óljóst hvernig ferlið ætti sér stað og hvaða prótein kæmu við sögu.

Grundvallarbreyting varð síðan á rannsóknum tengdum sjálfsáti upp úr 1990 pegar Ohsumi tókst að skilgreina gen sem eru nauðsynleg fyrir sjálfsátsferlið. Hann útbjó stökkbreyttan gersveppastofn sem hafði ekki virk ensím sem eru nauðsynleg fyrir niðurbrot í leysikornum (vacuole í gersveppum). Pegar slíkir sveppir voru sveltir varð greinileg uppsöfnun á sjálfsátsbólum innan leysikorns gersveppsins. ${ }^{2}$ Petta var vegna pess að við svelti jókst myndun sjálfsátsbóla en eftir samruna við leysikornið varð ekki niðurbrot í stökkbreyttum gersveppunum. Pví var ljóst að sjálfsátsferlið er virkt í gersveppum en auk pess hafði Ohsumi útbúið stofn sem mátti nýta til pess að greina gen sem eru nauðsynleg fyrir myndun sjálfsátsbóla. Hann framkallaði stökkbreytingar í erfðamengi pessa gersveppastofns og skilgreindi sem sjálfsátsgen pau gen sem leiddu til pess að svipgerðin hvarf. ${ }^{3}$

Ohsumi og fleiri fundu síðar að sjálfsátsgen gersveppsins eru einnig varðveitt í spendýrum, par með talið mönnum. ${ }^{4}$ Í kjölfarið hefur orðið mikil aukning á rannsóknum á ferlinu. Fljótlega var farið að skilgreina virkni peirra próteina sem sjálfsátsgen skrá fyrir og mögulegt varð að skoða áhrif sjálfsáts á ýmsar svipgerðir tilraunalífvera. ${ }^{5}$ Til dæmis hafa rannsóknir í ávaxtaflugum og ormum leitt í ljós að takmörkun ætis upp að ákveðnu marki eykur lífslengd pessara dýra. Pessi áhrif verða vegna aukningar sjálfsáts við minnkun ætis. Pannig er talið að jafnvægi næringar og hreinsunar frumunnar sé mikilvægt fyrir lífslengd pessara dýra.

Einnig hefur komið í ljós að sjálfsátsferlið er mikilvægt fyrir ýmsa aðra ferla, svo sem fósturproskun og sérhæfingu frumna, auk sýkingavarna par sem frumur nýta sjálfsát til pess að eyða óboðnum gestum. Pá hefur sjálfsát verið tengt ýmsum sjúkdómum, einkum taugasjúkdómum og krabbameinum. Niðurbrot er mikilvægt fyrir eðlilega frumustarfsemi pannig að gölluð prótein og frumulíffæri geti endurnýst fyrir nýbyggingu. Ef galli er til staðar í sjálfsátsferlinu verður uppsöfnun á skemmdum afurðum, sem getur verið skaðlegt og getur til dæmis valdið uppsöfnun á hvarfgjörnum sameindum og aukið skemmdir í erfðamenginu. Talið er að heilbrigt sjálfsát geti komið í veg fyrir æxlismyndun en á hinn bóginn getur sjálfsát ýtt undir æxlisvöxt á síðari stigum æxlismyndunar, meðal annars vegna myndunar niðurbrotsefna til uppbyggingar fyrir krabbameinsfrumur í næringar- eða súrefnissnauðu umhverfi. Pannig er nú verið að skoða sjálfsátshamla sem möguleg krabbameinslyf.

Nóbelsverðlaunin í læknavísindum í ár endurspegla ekki eingöngu mikilvægi sorphirðu og endurvinnslu í frumum - heldur líka í breiðara samhengi mikilvægi grunnrannsókna. Ohsumi hóf rannsóknir á sjálfsáti fyrir tæpum aldarfjórðungi pegar lítið sem ekkert var vitað um ferlið sem gegnir lykilhlutverki í niðurbroti í frumum. Rannsóknir hans póttu til að byrja með hvorki spennandi né áhugaverðar. Hins vegar hefur í kjölfar peirra orðið bylting í vitneskju okkar um pessa grundvallarstarfsemi frumna og nú er verið að próa lyf til pess að hafa áhrif á sjálfsátsferlið í tengslum við ýmsa sjúkdóma. Pannig er mikilvægt að hafa í huga að lyfjapróun og frampróun læknavísinda byggir að miklu leyti á rannsóknum sem eru ekki alltaf metnar til fulls af samtímanum. Rannsóknir eins og pær sem Ohsumi stundaði, á frumuferli í gersvepp, eru hins vegar nauðsynlegar og mikilvægt að styðja pær og efla.

\section{Heimildir}

1. Ohsumi Y. Historical landmarks of autophagy research. Cell Res 2014; 24, 9-23.

2. Takeshige $K$, Baba M, Tsuboi S, Noda T, Ohsumi Y. Autophagy in yeast demonstrated with proteinase-deficient mutants and conditions for its induction. J Cell Biol 1992; 119: 301-11. 3. Tsukada M, Ohsumi Y. Isolation and characterization of autophagy-defective mutants of Saccharomyces cerevisiae. FEBS Lett 1993; 333: 169-74.

4. Mizushima N, Noda T, Yoshimori T, Tanaka Y, Ishii T, George MD, et al. A protein conjugation system essential for autophagy. Nature 1998; 395: 395-8.

5. Ichimura Y, Kirisako T, Takao T, Satomi Y, Shimonishi Y, Ishihara N, et al. A ubiquitin-like system mediates protein lipidation. Nature 2000; 408: 488-92. 